\title{
Distribution of HCV Genotypes in the Populations of Inmates in Polish Prison Potulice and Patients Hospitalised in Bydgoszcz
}

\author{
Malgorzata Tyczyno ${ }^{1, *}$; Waldemar Halota ${ }^{1}$; Wojciech Nowak ${ }^{1}$; Małgorzata Pawlowska ${ }^{1}$ \\ ${ }^{1}$ Department of Infectious Diseases and Hepatology, Nicolaus Copernicus University, Bydgoszcz, Poland \\ ${ }^{*}$ Corresponding Author: Małgorzata Tyczyno, Department of Infectious Diseases and Hepatology, Nicolaus Copernicus University, Bydgoszcz, Poland. Tel: +48-523255678, Fax: +48- \\ 523255673. E-mail: m.tyczyno@op.pl
}

Received: September 16, 2013; Revised: December 12, 2013; Accepted: December 25, 2013

\begin{abstract}
Background: According to many studies, one of the social groups with high rate of HCV infections are prisoners.
Objectives: The aim of the study was to determine and compare the genotypes distribution among prisoners and patients of hospital. Patients and Methods: HCV genotypes among prisoners (281 inmates) and patients of hospital (1415 patients) were determined in years 2002-2012. HCV genotypes were determined in 2002-2005 with INNO-LiPA HCV II test (Innogenetics, Gent, Belgium) and since 2006 with LINEAR ARRAY assay (Roche, Mannheim, Germany), after isolation and amplification of the material with COBAS AMPLICOR v 2.0 (Roche, Mannheim, Germany).

Results: The most frequent HCV genotype among inmates was genotype 3, which was detected in169 of 281 patients (60.1\%). Most frequent genotype among hospitalized was genotype 1, which was found in 1127 cases (79.6\%). Comparing the results of prisoners with a group of patients with HIV/HCV co-infection gave similar results. In both groups most frequent was genotype 3 (respectively 60.1 and $45.5 \%$ ). However, most prisoners in this study (96\%) were HIV-negative.

Conclusions: The current study shows that the predominant HCV genotype among inmates from prison in Potulice is genotype 3.
\end{abstract}

Keywords: Hepatitis C; HCV; Prison

\section{Background}

According to the estimations of the World Health Organization about $3 \%$ of people (170-200 million) worldwide are infected with hepatitis $\mathrm{C}$ virus (HCV). The prevalence of HCV infection varies throughout the world. The smallest percentage, about 1\%, reported in north-western Europe, North America and Australia. The highest number of infections reported in Egypt (about 22\%).

In Europe the smallest amount of HCV infection, approximately $0.5 \%$ is reported in the northern part. It is estimated that $1 \%$ of infected persons live in the north-western part of the continent, $2 \%$ in the east and as many as $4.6 \%$ in the Mediterranean. In Poland infected are approximately $1.5 \%$ of the population $(1,2)$. In the HCV genome were observed differences in the nucleotide sequence of the region encoding the nonstructural protein (NS5). On the basis of the similarity of nucleotide sequence genotypes, subtypes and quasispecies were separated. This similarity in the case of genotypes ranges between 65, 7 and $68,9 \%$. Whereas in subtypes the range is from 76,9 to $80,1 \%$, quasispecies it is $90,8-99 \%$ of similarity of nucleotide sequence (3). There are six main genotypes of HCV. Their presence in the world is diversified geographically. Genotypes 1 and 2 are the most common in Europe, the
United States of America and Japan (4). Genotype 3 is mainly in Europe and the United States of America, particularly among intravenous drug users, as well as in India and Pakistan $(2,5,6)$. Genotype 4 is the most common in the Middle East and Africa, 5 in South Africa and 6 in Asia $(7,8)$. In Vietnam genotypes 7, 8 and 9 were identified; in Indonesia, 10 and 11 because their presence is more local, the standardized nomenclature classified them into one group - genotype 6 (9). It has been observed that not only the geographical distribution may affect the type of genotype. Age, route of infection, and co-infections may also have influence (10-12).

Regardless of the geographic variable, the incidence of HCV infection may vary in certain social groups. One such group are the prisoners. Within this group HCV infection was found in $20-47 \%$ of inmates (13-15). In these patients, the HCV infection occurs mainly as a result of intravenous drug use, unprotected sex and tattooing or piercing. Wherein it is believed that the HCV infection in these patients group may occur both before and during incarceration $(16,17)$.

\section{Objectives}

The aim of the study was to determine and compare the

Implication for health policy makers/practice/research/medical education:

Prisoners are one of the social groups with high rate of HCVinfections. This manuscript can help understand distribution of different HCV genotypes among prisoners.

Copyright (C) 2014, Kowsar Corp;; Published by Kowsar Corp. This is an open-access article distributed under the terms of the Creative Commons Attribution License, which permits unrestricted use, distribution, and reproduction in any medium, provided the original work is properly cited. 
genotypes distribution among prisoners and patients hospitalised in Bydgoszcz. Because according to many studies, one of the social groups with high rate of HCV infections are prisoners, and no study has been done in order to determine HCV genotypes in group of inmates.

\section{Patients and Methods}

The study involved 281 inmates from prison in Potulice (group I) and 1415 adult persons from Department of Infectious Diseases in Bydgoszcz (group II). All diagnosed in hospital in Bydgoszcz in years 2002-2012 due to HCV infection. Among patients from Bydgoszcz there was an isolated group of 132 patients with HIV/HCVco-infection (group III). HCV genotypes were determined in 20022005 with INNO-LiPA HCV II test (Innogenetics, Gent, Belgium) and since 2006 with LINEAR ARRAY assay (Roche, Mannheim, Germany), after isolation and amplification of the material with COBAS AMPLICOR v 2.0 (Roche, Mannheim, Germany).

\section{Results}

Comparison of the results showed significant differences in the prevalence of HCV genotypes in different groups (Table 1).

Among group I prevailed genotype 3 , which was detected in 169 of 281 patients (60.1\%). Genotype 1 was present in $33.5 \%$ and 4 in $6.4 \%$ of inmates. In group II observation showed more frequently genotype 1 , which was found in 1127 cases (79.6\%). Genotypes 3 and 4 were similar, they were detected respectively in 161 and126 of 1415 adult patients. Comparison of the results from patients within group I and III gave similar results (Table 2). In both groups genotype 3 (respectively 60.1 and $45.5 \%$ ) was most frequent. Genotype 1 has performed with nearly identical frequencies: 33.5 and $33.3 \%$. Genotype 4 was found in $6.4 \%$ of group II and $21.2 \%$ of group III.

Table 1. HCV Genotype in Group Inmates (I) and Hospitalized (II) ${ }^{\mathrm{a}}$

\begin{tabular}{llccc}
\hline Group & \multicolumn{1}{c}{$\mathbf{1}$} & $\mathbf{2}$ & $\mathbf{3}$ & $\mathbf{4}$ \\
\hline Inmates $(\mathbf{I}), \mathbf{n}=\mathbf{2 8 1}$ & $94(33,5)$ & & $169(60,1)$ & $18(6,4)$ \\
Hospitalised (II), $\mathbf{n}=$ & $1127(79,6)$ & $1(0,1)$ & $161(11,4)$ & $126(8,9)$ \\
$\mathbf{1 4 1 5}$ & & & & \\
\hline a Data are presented in No.\%. & & & &
\end{tabular}

$\mathrm{a}$ Data are presented in No.\%.

\begin{tabular}{l}
\hline \begin{tabular}{lccc}
\hline Table 2. HCV Genotype in Group Inmates (I) and HIV/HCV (III) & a \\
\hline Group & $\mathbf{1}$ & $\mathbf{2}$ & $\mathbf{3}$ \\
\hline Inmates (I), $\mathbf{n}=\mathbf{2 8 1}$ & $94(33,5)$ & $169(60,1)$ & $18(6,4)$ \\
HIV/HCV (III), $\mathbf{n}=\mathbf{1 3 2}$ & $44(33,3)$ & $60(45,5)$ & $28(21,2)$ \\
\hline
\end{tabular}
\end{tabular}

a Data are presented in No.\%.

\section{Discussion}

HCV genotype 3 was dominant, detected in $60 \%$ of patients diagnosed in Potulice. It seems that these results may be related to a tightness of the group. This may be the reason in the distribution differences of HCV genotypes obtained during the study of their occurrence among prisoners in the world. In Spain and Canada HCV genotype1 and 3 occurred at similar rates (respectively about 50 and 30\%). Among the prisoners in Spain the presence of genotype 4 in $17 \%$ of patients was also found. This type has not been detected among Canadian prisoners, instead of $12 \%$ of genotype $2(18,19)$. The Brazilian researchers have found the presence of genotype 1 in $91 \%$ of prisoners (20). Research has indicated that the most common type of HCV with patients from Bydgoszcz is genotype 1 , occurring at less than $80 \%$ of the respondents. These results coincide with those obtained in 2006, when the genotype 1 was found in over $80 \%$ of adult patients in Bydgoszcz (21). Similarly Chlabicz et al. demonstrated the predominance of genotype 1 in the study group, reported it in $57 \%$ of patients (22). This is in line with other European reports, where genotype 1 was detected in $68-90 \%$ of patients $(23,24)$. The incidence of HCV genotypes among inmates in Potulice was similar to that which was found among a group of patients with HIV/HCV co-infection diagnosed in Bydgoszcz. In both groups genotype $3 \mathrm{HCV}$ is the most common. However, among patients in Potulice only $4 \%$ of them have HIV/HCV co-infection. Similar results of HCV genotypes distribution among HIV/HCV co-infected patients were also received by Grabczewska and Babik, Holodniy $(25,26)$, they demonstrated the predominance of genotype 3 in 50-60\% of cases. Karakulova and Power demonstrated the predominance of genotype 1 among HIV/HCV co-infected patients $(27,28)$. Similarly to the prisoners these results may be related to the tightness of the group.

Likewise, such a predominance of HCV genotype 3 was demonstrated also in HCV monoinfected patients. These patients indicated intravenous drug use as the likely source of HCV infection $(12,22)$. During the examination, 125 of the 281 patients from Potulice indicated intravenous drug use as the probable source of HCV infection. Of these, $56 \%$ had genotype $3 \mathrm{HCV}$; genotype 1 was present in $25.5 \%$ and 4 in $18.5 \%$ of inmates in Potulice.

The above results require further studies in larger patient populations.

\section{Acknowledgements}

This work was supported by Department of Infectious Diseases and Hepatology Collegium Medicum in Bydgoszcz Nicolaus Copernicus University.

\section{Authors' Contribution}

Study concept, design and critical revision of the manuscript for important intellectualcontent: Halota, Paw- 
lowska, Tyczyno and Nowak. Acquisition of data: Tyczyno and Nowak. Analysis and interpretation of data: Tyczyno and Pawlowska. Drafting of the manuscript and statistical analysis: Tyczyno. Study supervision: Halota, Pawlowska.

\section{Financial Disclosure}

All authors declare that they have no financial disclosures and no conflicts of interest to report.

\section{Funding/Support}

This work was supported by Department of Infectious Diseases and Hepatology, Nicolaus Copernicus University, Bydgoszcz, Poland.

\section{References}

1. Sy T, Jamal MM. Epidemiology of hepatitis $\mathrm{C}$ virus (HCV) infection. Int J Med Sci. 2006;3(2):41-6.

2. Shepard CW, Finelli L, Alter MJ. Global epidemiology of hepatitis C virus infection. The Lancet Infectious Diseases. 2005;5(9):55867.

3. Zein NN. Clinical significance of hepatitis C virus genotypes. Clin Microbiol Rev. 2000;13(2):223-35.

4. Fattovich G, Ribero ML, Pantalena M, Diodati G, Almasio P, Nevens F, et al. Hepatitis C virus genotypes: distribution and clinical significance in patients with cirrhosis type $\mathrm{C}$ seen at tertiary referral centres in Europe. J Viral Hepat. 2001;8(3):206-16.

5. Singh B, Verma M, Verma K. Markers for transfussion-associaced hepatitis in north Indian blood donors: prevalence and trends. Jpn I Infect Dis. 2004;57(2):49-51.

6. Idrees M, Riazuddin S. Frequency distribution of hepatitis $C$ virus genotypes in different geographical regions of Pakistan and their possible routes of transmission. BMC Infect Dis. 2008;8:69.

7. Nguyen MH, Keeffe EB. Prevalence and Treatment of Hepatitis C Virus Genotypes 4, 5, and 6. Clinical gastroenterology and hepatology : the official clinical practice journal of the American Gastroenterological Association. 2005;3:S97-S101.

8. Ramia S, Eid-Fares J. Distribution of hepatitis $C$ virus genotypes in the Middle East. Int J Infect Dis. 2006;10(4):272-7.

9. Lauer GM, Walker BD. Hepatitis C virus infection. $N$ Engl J Med. 2001;345(1):41-52.

10. Meyer MF, Wedemeyer H, Monazahian M, Dreesman J, Manns MP, Lehmann M. Prevalence of hepatitis C in a German prison for young men in relation to country of birth. Epidemiol Infect. 2007;135(2):274-80

11. Zarski JP, Bohn B, Bastie A, Pawlotsky JM, Baud M, Bost-Bezeaux $\mathrm{F}$, et al. Characteristics of patients with dual infection by hepatitis B and C viruses. Journal of Hepatology:;28(1):27-33.

12. Stroffolini T, D'Egidio PF, Aceti A, Filippini P, Puoti M, Leonardi $\mathrm{C}$, et al. Hepatitis $\mathrm{C}$ virus infection among drug addicts in Italy.
J Med Virol. 2012;84(10):1608-12.

13. Weild AR, Gill ON, Bennett D, Livingstone SJ, Parry JV, Curran L. Prevalence of HIV, hepatitis B, and hepatitis C antibodies in prisoners in England and Wales: a national survey. Commun Dis Public Health. 2000;3(2):121-6.

14. Skipper C, Guy JM, Parkes J, Roderick P, Rosenberg WM. Evaluation of a prison outreach clinic for the diagnosis and prevention of hepatitis C: implications for the national strategy. Gut. 2003;52(10):1500-4.

15. Kassaian N, Adibi P. Hepatitis C virus and associated risk factors among prison inmates with history of drug injection in Isfahan, Iran. Int J Prev Med. 2012;3(Suppl1):165-1.

16. Vallabhaneni S, Macalino GE, Reinert SE, Schwartzapfel B, Wolf FA, Rich JD. Prisoners favour hepatitis $\mathrm{C}$ testing and treatment. Epidemiol Infect. 2006;134(2):243-8.

17. Allwright S, Bradley F, Long J, Barry J, Thornton L, Parry JV. Prevalence of antibodies to hepatitis B, hepatitis C, and HIV and risk factors in Irish prisoners: results of a national cross sectional survey. BMJ. 2000;321(7253):78-82.

18. Murcia J, Portilla J, Bedia M, Palazon JM, Sanchez-Paya J, Saiz de la Hoya P, et al. [Chronic hepatitis $C$ virus infection and associated liver disease among the inmates of a Spanish prison]. Enferm Infecc Microbiol Clin. 2009;27(4):206-12.

19. Farley JD, Wong VK, Chung HV, Lim E, Walters G, Farley TA, et al. Treatment of chronic hepatitis $C$ in Canadian prison inmates. Can J Gastroenterol. 2005;19(3):153-6.

20. Santos BF, de Santana NO, Franca AV. Prevalence, genotypes and factors associated with HCV infection among prisoners in Northeastern Brazil. World J Gastroenterol. 2011;17(25):3027-34.

21. Tyczyno M. HCV genotypes among patients diagnosed in Bydgoszcz. MSR Hepatol. 2007;7:77-9.

22. Chlabicz S, Flisiak R, Kowalczuk O, Grzeszczuk A, Pytel-Krolczuk B, Prokopowicz D, et al. Changing HCV genotypes distribution in Poland-relation to source and time of infection.J Clin Virol. 2008;42(2):156-9.

23. Januszkiewicz-Lewandowska D, Wysocki J, Rembowska J, Pernak M, Lewandowski K, Nowak T, et al. Transmission of HCV infection among long-term hospitalized onco-haematological patients. J Hosp Infect. 2003;53(2):120-3.

24. Touceda S, Pereira M, Agulla A. Prevalence of hepatitis C virus genotype in the areao of El Ferrol (La Coruna, Spain). . Enferm Infecc Microbiol Clin. 2002;20(5):200-4.

25. Grabczewska E, Pawlowska M, Halota W. Epidemiological aspects of HCV-HIV co-infections. HIV AIDS Rev. 2003;2:123-6.

26. Babik JM, Holodniy M. Impact of highly active antiretroviral therapy and immunologic status on hepatitis $C$ virus quasispecies diversity in human immunodeficiency virus/hepatitis C virus-coinfected patients. J Virol. 2003;77(3):1940-50.

27. Krekulova L, Rehak V, Madrigal N. Genotypic and epidemiologic characteristics of hepatitis $C$ virus infection among recent injection drug users and nonusers populations. Clin Infect Dis. 2001;15(8):1435-8.

28. Poveda E, Vispo E, Barreiro P, de Mendoza C, Labarga P, Fernandez-Montero JV, et al. Predicted effect of direct acting antivirals in the current HIV-HCV-coinfected population in Spain. Antivir Ther. 2012;17(3):571-5. 